\title{
Relationship between Serum Adalimumab Levels and Clinical Outcome in the Treatment of Inflammatory Bowel Disease
}

\author{
Joaquín Hinojosa ${ }^{a} \quad$ Fernando Muñoz $^{b} \quad$ Gregorio Juan Martínez-Romero ${ }^{c}$ \\ a Servicio de Medicina Digestiva, Hospital Universitario de Manises, Valencia, Spain; b Servicio de Digestivo, Hospital \\ Clínico Universitario de Salamanca, Salamanca, Spain; ' Servicio de Farmacia, Hospital Universitario de Manises, \\ Valencia, Spain
}

\section{Keywords}

Inflammatory bowel disease · Inflammation · Crohn's

disease $\cdot$ Ulcerative colitis

\begin{abstract}
Background: Adalimumab (ADA) is an anti-tumor necrosis factor agent that has been shown to be effective in inducing and maintaining remission in adult patients with inflammatory bowel disease. The relationship between the ADA trough levels and clinical efficacy has been demonstrated, but there is variability in the definition of the most suitable range for its clinical applicability. Summary: A review of published studies during the last 5 years on ADA serum levels and its relationship with the clinical outcome was performed. The studies selected included 7 observational studies, a systematic review, a meta-analysis and a post hoc analysis of a clinical trial. The reported ADA levels that discriminate patients in clinical remission from those with active disease range from 4.5 to $8 \mu \mathrm{g} / \mathrm{mL}$. This therapeutic range varies when considering endoscopic remission ( 7.5 to $>13.9 \mu \mathrm{g} /$ $\mathrm{mL}$ ). Although the sample of patients with ulcerative colitis
\end{abstract}

() 2019 S. Karger AG, Basel is small, a tendency to reach higher levels of ADA is observed in both clinical and endoscopic remission. Key Messages: The optimal therapeutic cut-off point of serum ADA levels ranges from $4.5-5$ to $12 \mu \mathrm{g} / \mathrm{mL}$, where ADA levels are associated with an adequate clinical monitoring of the disease during maintenance therapy. These ranges vary according to the target, suggesting levels of $4.8 \mu \mathrm{g} / \mathrm{mL}$ as the cut-off for clinical remission and levels $\geq 7.5 \mu \mathrm{g} / \mathrm{mL}$ for mucosal healing/endoscopic response. Controlled prospective studies are required to determine the optimal therapeutic interval of ADA serum levels both as induction and as maintenance therapy.

(c) 2019 S. Karger AG, Basel

\section{Introduction}

Crohn's disease (CD) and ulcerative colitis (UC) are chronic diseases characterized by gastrointestinal tract inflammation, with a severe impact on the quality of life of patients. Tumor necrosis factor alpha (TNFa) plays a crucial role in their pathogenesis and is the target of bio-

\section{KARGER}

E-Mail karger@karger.com

www.karger.com/ddi
Dr. Joaquín Hinojosa

Servicio de Medicina Digestiva, Hospital Universitario de Manises

Avenida de la Generalitat Valenciana

50, ES-46940 Valencia (Spain)

E-Mail jhinojosad@gmail.com 


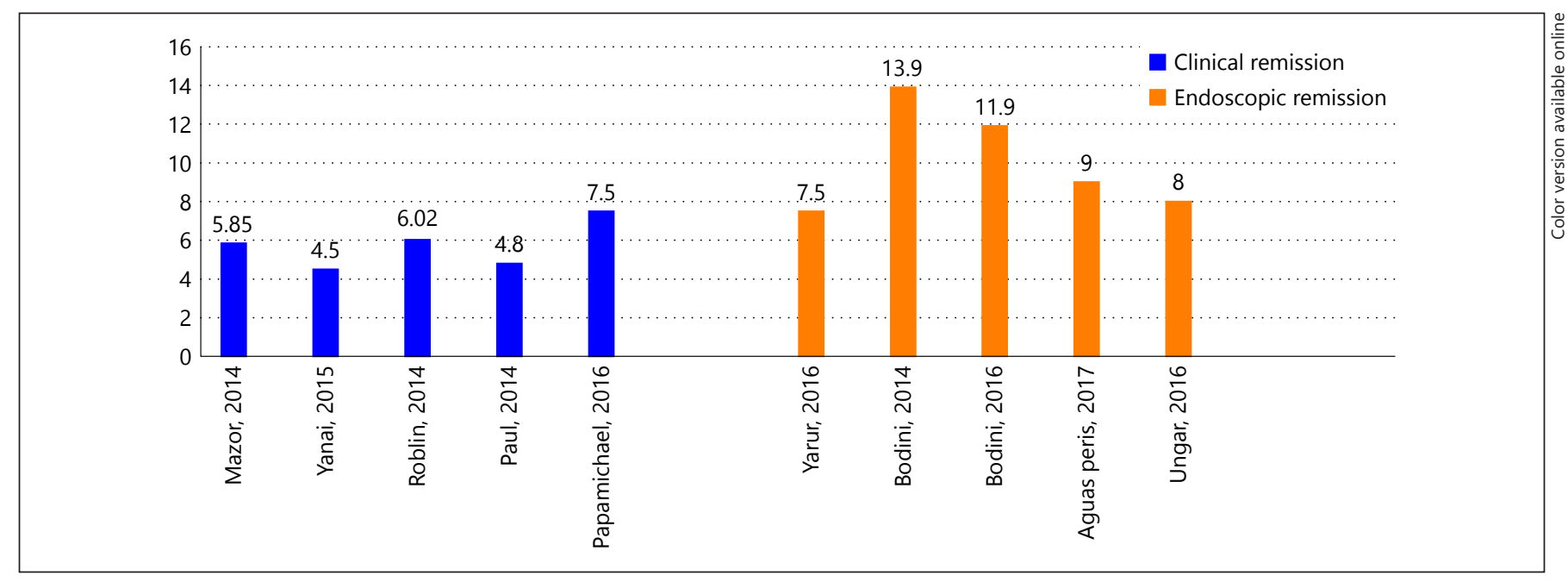

Fig. 1. Cut-off levels of ADA in clinical and endoscopic remission.

logic therapies for inflammatory bowel disease (IBD) [1]. Adalimumab (ADA) is a monoclonal immunoglobulin G1 antibody that binds with high affinity and specificity to human TNF [2]. ADA is an anti-TNF agent that has been shown to be effective in inducing and maintaining remission in patients with IBD [2-5]. Anti-TNF therapy is effective only in almost half the IBD patients, and $40 \%$ of patients who initially respond to therapy ultimately relapse within a year [6,7]. A number of underlying factors could explain such a lack of efficacy, as the production of anti-TNF antibodies, TNF and anti-TNF tissue levels, serum levels of $\mathrm{C}$-reactive protein, $\mathrm{BMI}$, serum albumin, and serum levels of anti-TNF [3,8-11]. These factors might explain inter-individual variability in clinical and histological outcomes of anti-TNF therapy at the recommended doses [12]. Among these factors, serum levels of anti-TNF can be controlled.

Serum ADA quantification used in combination with clinical data of the patient could be useful for the clinical management of IBD patients [6]. When ADA levels are used only if there is a loss of response, management is called a reactive monitoring [13]. Management is called "proactive monitoring" when patients are in remission and ADA levels are quantified to guide dose titration aimed at avoiding a lack or loss of response [13]. Since the publication of the studies on which their approval was based, many studies have been performed to assess the correlation between serum ADA levels in IBD patients and clinical, endoscopic, and histological outcomes [14]. In this sense, it is necessary that serum ADA level cut-off points (therapeutic interval] are established to ensure that
ADA therapy is effective and predict its loss of efficacy in IBD patients. A review of the literature was conducted to gather data that guide decision-making in IBD patients receiving ADA.

\section{Materials and Methods}

A review of the studies published in English and Spanish was performed on PUBMED, the Cochrane Library, and EMBASE databases in the last 5 years until present (December 1, 2017). Search words included: "drug monitoring, serum levels, ADA, anti-TNF, IBD, CD, UC, outcome, remission, healing". Clinical trials, clinical studies, systematic reviews, and meta-analyses were included. Then, abstracts were reviewed to identify studies aimed at assessing the correlation between serum ADA levels and clinical outcomes.

\section{Results}

A total of 71 references were initially identified including clinical trials, observational studies, clinical studies, meta-analyses, and systematic reviews.

Articles related to the relationship between ADA trough levels and clinical outcomes were selected, excluding those that related ADA trough levels with antiADA antibodies or with interleukin concentrations of inflammation, and other publications on different techniques of analysis of ADA levels. After the selection process, the number of references finally selected for review was 11 . 
Table 1. Summary of the publications included

\begin{tabular}{|c|c|c|c|c|}
\hline Publications & Year & Study design & Population & Clinical impact of serum ADA level \\
\hline $\begin{array}{l}\text { Mazor } \\
\text { et al. [15] }\end{array}$ & 2014 & Cross-sectional & $71 \mathrm{CD}$ & $\begin{array}{l}\text { - } 5.85 \mu \mathrm{g} / \mathrm{mL} \text { was the adequate cut-off point to predict remission } \\
\text { - ADA levels were inversely related to disease activity }\end{array}$ \\
\hline $\begin{array}{l}\text { Yanai } \\
\text { et al. [10] }\end{array}$ & 2015 & Retrospective & & $\begin{array}{l}\text { - } 4.5 \mu \mathrm{g} / \mathrm{mL} \text { was considered adequate } \\
\text { - TDM was useful for guiding dose titration on suspicion of loss of } \\
\text { response or definitive inflammatory loss of response }\end{array}$ \\
\hline $\begin{array}{l}\text { Bodini } \\
\text { et al. [17] }\end{array}$ & 2014 & $\begin{array}{l}\text { Post-hoc analysis } \\
\text { of a clinical trial }\end{array}$ & $6 \mathrm{CD}$ & $\begin{array}{l}\text { - Levels were lower in patients with clinical or endoscopic recurrence } \\
\text { than in patients in remission }(7.5 \mathrm{vs} .13 .9 \mu \mathrm{g} / \mathrm{mL}, p<0.01) \\
\text { - TDM was useful for reducing postoperative recurrence }\end{array}$ \\
\hline $\begin{array}{l}\text { Aguas Peris } \\
\text { et al. [19] }\end{array}$ & 2017 & $\begin{array}{l}\text { Prospective } \\
\text { observational }\end{array}$ & $\begin{array}{l}71 \mathrm{CD} \\
16 \mathrm{UC}\end{array}$ & $\begin{array}{l}\text { - ADA levels in CD patients in remission were significantly higher } \\
(p=0.009) \text { than in patients with active disease }(9.2 \mathrm{vs} .6 .0 \mu \mathrm{g} / \mathrm{mL}) \\
\text { - ADA levels in UC patients in remission were significantly higher } \\
(p=0.002) \text { than in patients with active disease }(14.4 \mathrm{vs} .5 .2 \mu \mathrm{g} / \mathrm{mL})\end{array}$ \\
\hline $\begin{array}{l}\text { Ungar } \\
\text { et al. [1] }\end{array}$ & 2016 & Cross-sectional & $\begin{array}{l}58 \mathrm{CD} \\
9 \mathrm{UC}\end{array}$ & $\begin{array}{l}\text { - ADA levels were higher in patients with mucosal healing than in } \\
\text { patients with active disease ( } 6.2 \mathrm{vs} .3 .1 \mu \mathrm{g} / \mathrm{mL}, p=0.01 \text { ) } \\
\text { - ADA levels ranging from } 8 \text { and } 12 \mu \mathrm{g} / \mathrm{mL} \text { are estimated to be } \\
\text { necessary for attaining mucosal healing in } 80-90 \% \text { of patients with } \\
\text { BID }\end{array}$ \\
\hline $\begin{array}{l}\text { Roblin } \\
\text { et al. [20] }\end{array}$ & 2014 & Cross-sectional & $\begin{array}{l}22 \mathrm{CD} \\
18 \mathrm{UC}\end{array}$ & $\begin{array}{l}\text { - ADA levels were higher in patients in clinical remission than in } \\
\text { patients with active disease }(6.02 \mathrm{vs.} 3.2 \mu \mathrm{g} / \mathrm{mL}, p=0.012) \\
\text { - ADA levels } \geq 4.85 \mu \mathrm{g} / \mathrm{mL} \text { are associated with clinical remission } \\
\text { - ADA levels }<4.9 \mu \mathrm{g} / \mathrm{mL} \text { are associated with a lack of mucosal healing }\end{array}$ \\
\hline $\begin{array}{l}\text { Papamichael } \\
\text { et al. [23] }\end{array}$ & 2017 & Retrospectivo & $43 \mathrm{UC}$ & $\begin{array}{l}\text { - Mucosal healing: ADA levels }>10.6 \mu \mathrm{g} / \mathrm{mL} \text { in week } 4 \text {. Below } \\
7.4 \mu \mathrm{g} / \mathrm{mL} \text { there is no mucous cure } \\
\text { - Levels in week } 4 \geq 7.5 \mu \mathrm{g} / \mathrm{mL} \text { are associated with less loss of } \\
\text { clinical response }\end{array}$ \\
\hline
\end{tabular}

CD, Crohn's disease; UC, ulcerative colitis; ADA, adalimumab.

After a review of the literature, 7 observational studies, a systematic review and meta-analysis, and the post hoc analysis of a clinical trial were valid for the analysis. Although 2 of the studies (Mazor et al. [15], and Bodini et al. [17]) were included in the meta-analysis, they have been considered important enough to be explained separately. The characteristics of the studies included are summarized in Table 1.
Mazor et al. [15], conducted a cross-sectional study in 71 patients with $\mathrm{CD}$ treated with ADA. The analysis of 118 serum samples revealed that high serum ADA levels were associated with clinical remission (area under curve $0.748, p<0.001$ ). Based on the results obtained, the authors established a cut-off point of $5.85 \mu \mathrm{g} /$ $\mathrm{mL}$ for serum ADA levels to predict remission $(68 \%$ sensitivity, $70.6 \%$ specificity, and 2.3 positive probability 
ratio). The conclusion drawn was that an inverse relationship existed between high serum ADA levels and disease activity.

Yanai et al. [10] performed a multicenter retrospective study in 247 IBD patients with suspected loss of response to anti-TNF agents (infliximab or ADA). Loss of response occurred 330 times, 142 of which occurred in patients treated with ADA. The results of this study revealed that patients with suspected loss of response and stable ADA levels $>4.5 \mu \mathrm{g} / \mathrm{mL}$ did not respond to an increased dose or shift to another anti-TNF agent. In consequence, $4.5 \mu \mathrm{g} /$ $\mathrm{mL}$ was established as cut-off point. In the same line, the authors observed that the duration of response in patients with adequate ADA levels (i.e., $>4.5 \mu \mathrm{g} / \mathrm{mL}$ ) was higher when ADA was replaced with an agent of a different class than when ADA dose was increased or replaced with another anti-TNF. The results of this study evidenced that an ADA level cut-off point could be useful for the therapeutic management (dose titration, changing to another anti-TNF, changing to a different-class biological agent) of IBD patients treated with ADA.

Paul et al. [14] conducted a systematic review and a meta-analysis of all data available as of 2013. Fourteen studies were included in the systematic review (4 controlled clinical trials, 4 prospective cross-sectional studies, 5 observational studies, and a retrospective study), 11 of which were performed in CD patients, 2 in UC patients, and one included both types of patients. Serum ADA levels and clinical outcomes were assessed in 13 of the 14 studies included. Notably, a correlation was not found between high serum ADA levels and outcomes in just one study. The authors of this study concluded that the optimal cut-off point for serum ADA levels ranged between 4.8 and $5.9 \mu \mathrm{g} / \mathrm{mL}$, which was consistent with the optimal cut-off points identified in another 4 of the studies included in the systematic review. Six studies were included in the meta-analysis (with a total of 536 patients with CD). The results obtained revealed that patients with serum ADA levels above the cut-off point previously set were more likely to be in clinical remission. The authors concluded that high trough levels of ADA (TRA) were associated with higher rates of response in patients with CD.

A cross-sectional study carried out by Yarur et al. [16], in 66 patients (59 with CD and 7 with UC) treated with ADA showed that mean serum ADA levels were lower in patients with histological and endoscopic inflammation ( 9.2 vs. $14.1 \mu \mathrm{g} / \mathrm{mL}, p=0.03$, and 8.5 vs. $13.3 \mu \mathrm{g} / \mathrm{mL}, p=$ 0.02 , respectively). ADA levels $\geq 7.5 \mu \mathrm{g} / \mathrm{mL}$ were found to be correlated with the absence of endoscopic lesions.
However, sensitivity was low. The explanation offered by the authors was that some patients may need to reach higher serum ADA levels to attain histological healing (the ADA level that best associated with histologic healing was $7.8 \mu \mathrm{g} / \mathrm{mL}$ ). These findings led the authors to conclude that the serum ADA levels necessary to reach histological and endoscopic healing may be higher than those reported in previous studies.

Bodini et al. [17] undertook a post hoc analysis of a clinical trial to explore the potential association between ADA levels and clinical and endoscopic outcomes in a series of 6 patients who received prophylactic ADA monotherapy after surgery. Patients without recurrence during the follow-up period ( 2 years) were found to have higher serum ADA levels. Of note, serum ADA levels in patients who experienced recurrence progressively decreased until recurrence. The conclusion drawn by the authors was that ADA levels after surgery in these patients may guide therapeutic and follow-up decisionmaking and help reduce recurrence rates following surgery in $\mathrm{CD}$ patients.

Bodini et al. [18] carried out a prospective observational study in 23 patients with CD treated with ADA. The results obtained revealed that ADA levels at week 48 and at the end of follow-up (median follow-up: 102 weeks) were significantly higher in patients in remission than in patients with mild and moderate to severe disease (ADA levels 10.1, 7.4 and $4.5 \mu \mathrm{g} / \mathrm{mL}$ respectively, $p=$ 0.027). Serum ADA levels in patients in remission were 11.9 vs. $5.5 \mu \mathrm{g} / \mathrm{mL}$ in patients with mild and moderate to severe disease $(p=0.0002)$. Once again, emphasis was laid on the relevance of therapeutic drug monitoring (TDM) in the clinical management of $\mathrm{CD}$ patients treated with ADA.

Aguas Peris et al. [19] performed a prospective observational study in 87 patients with IBD (71 CD and $16 \mathrm{UC}$ ) treated with ADA. Serum ADA levels were observed to be associated with clinical remission. Thus, $9 \mu \mathrm{g} / \mathrm{mL}$ was considered an appropriate cut-off point to discriminate patients in clinical remission from patients with active disease. Additionally, the cut-off point $12.2 \mu \mathrm{g} / \mathrm{mL}$ correlated with a good course of disease if the ADA dose was reduced.

The cross-sectional study carried out by Ungar et al. [1], in 67 patients with IBD (58 CD and 9 UC) revealed that serum ADA levels were higher in patients with mucosal healing than in those with active disease (6.2 vs. 3.1 $\mu \mathrm{g} / \mathrm{mL}, p=0.01)$. ADA levels $>7.1 \mu \mathrm{g} / \mathrm{mL}$ indicated patients with mucosal healing with a specificity of $85 \%$. At $12 \mu \mathrm{g} / \mathrm{mL}$, a plateau was identified in the association be- 
Table 2. Therapeutic range of adalimumab levels estimated in CD and UC [12-14]

\begin{tabular}{|c|c|c|}
\hline Luminal disease & $\begin{array}{l}\text { Clinical } \\
\text { remission, } \\
\mu \mathrm{g} / \mathrm{mL}\end{array}$ & $\begin{array}{l}\text { Endoscopic } \\
\text { remission, } \\
\mu \mathrm{g} / \mathrm{mL}\end{array}$ \\
\hline Adalimumab EC & $4.8-5.9$ & $7.5-12$ \\
\hline Adalimumab CU & $\geq 7.4$ & $\geq 10.6$ \\
\hline
\end{tabular}

$\mathrm{CD}$, Crohn's disease; UC, ulcerative colitis.

tween high serum ADA levels and mucosal healing. Based on the results obtained, the authors concluded that 8-12 $\mu \mathrm{g} / \mathrm{mL}$ was necessary to achieve mucosal healing in 80 $90 \%$ of patients with BID.

In a cross-sectional study in $40 \mathrm{IBD}$ patients $(22 \mathrm{CD}$, 18 UC) [20], serum ADA levels were higher in patients in clinical remission than in those with active disease (6.02 $\mu \mathrm{g} / \mathrm{mL}$ vs. $3.2 \mu \mathrm{g} / \mathrm{mL}, p=0.012$ ). A cut-off point of 4.85 $\mu \mathrm{g} / \mathrm{mL}$ of serum ADA levels was associated with clinical remission, with a sensitivity of $81 \%$ and a specificity of $67 \%$, VPP $84 \%$ and VPN 57\%. The results obtained led the authors to conclude that serum ADA levels are significantly associated with clinical remission and mucosal healing. The optimal cut-off point for predicting these results was set at $4.85-4.9 \mu \mathrm{g} / \mathrm{mL}$.

The levels of the therapeutic range of ADA estimated in EC and CU are summarized in Table 2 and Figure 1.

\section{Discussion}

Although therapeutic decisions on IBD patients are mainly based on the clinical status of the patient, TDM of ADA presents as a useful tool for the management of IBD patients who receive induction and maintenance therapy with $\mathrm{ADA}[8,21,22]$. Thus, when a patient receives induction therapy, low serum ADA levels are associated with lack of response [23] and similarly when a patient receives maintenance $\mathrm{ADA}$ therapy, low serum $\mathrm{ADA}$ levels are correlated with loss of clinical and endoscopic response and lack of mucosal healing. In both situations, low serum ADA levels may predispose to the appearance of anti-ADA antibodies [24]. Therefore, ADA TDM could be useful for the therapeutic management of IBD patients and help optimize outcomes.

At first, most studies analyze trough levels as predictors of response to anti-TNF agents, but there are points of uncertainty about whether the peak levels after ad- ministration of the drug, levels at other points of the administration cycle, or exposure to the drug defined by the area under curve could be better indicators. However, few studies have evaluated these scenarios. Generally, the levels are measured once the plateau phase has been reached. It may also take months to achieve these objectives with ADA and infliximab. The half-life with both is long and there may be variability in the induction doses. On the other hand, the half-life of anti-TNFs depends on individual variables such as sex, body mass index, co-treatment with immunomodulators, albumin levels, inflammatory bowel activity, and loss of drug and antibodies through the intestine, which conditions both inter and intra-individual variability. With ADA, using trough levels as an indicator for decision making may be less critical due to less fluctuation in levels within the administration cycle. The abundance of data available illustrates the interest of researchers on exploring the correlation between serum ADA levels and ADA therapy efficacy $[1,7,10,14-20,25,26]$. Yet, the studies included in our review are heterogeneous and present some limitations. Serum ADA levels in patients on ADA maintenance therapy were assessed in all studies, and the majority of them had a retrospective cross-sectional design. However, most had a small sample and included patients receiving or not concomitant treatment with immunomodulators, and the sample of UC patients was generally small.

All this implies important limitations to set down conclusions, so the ranges for $\mathrm{ADA}$ in patients with $\mathrm{UC}$ should be applied with caution due to the low number of patients included. As it has been observed that anti-TNF levels do not correlate in a defined way with the risk of secondary events, the therapeutic range should be focused toward the optimization clinical efficacy.

Based on the data provided in the studies included in our review, optimal serum ADA level ranges from 4.5 to $8 \mu \mathrm{g} / \mathrm{mL}$. This cut-off is consistent with the one established by the American Gastroenterological Association [21]. The cut-off point set by American Gastroenterological Association was the result of a technical review of all the evidence available up to March 2016 in relation to the role of TDM in the management of IBD. The authors of this review observed that the percentage of patients not in remission progressively decreased from $17 \%$ when the $\geq 5 \pm 1 \mu \mathrm{g} / \mathrm{mL}$ cut-off was used (232 patients) to $10 \%$ with ADA levels of $\geq 7.5 \pm 1 \mu \mathrm{g} / \mathrm{mL}$. Only a few studies have been performed to compare ADA cut-off points for UC and $\mathrm{CD}$, which limits any type of analysis. It is worth 
mentioning that there is lack of high-quality RCT and comparative studies conducted with the same purposes as those of this study.

Despite the data obtained in the review of the different studies, the established objectives vary, mostly from clinical remission, or more broadly from the concept of response or non-response, to mucosal healing. We believe that this is an important point that limits the possibility of establishing conclusions that may have later applicability in real practice.

In order to establish a therapeutic range, it is fundamental to define the target that needs to be achieved because the clinical implications change. The STRIDE study has defined that the combination of clinical remission, based on the results referred by the patient together with the endoscopic remission, should be the endpoint to achieve both in the UC and CD.

There are clear limitations in the studies, which are evaluated to make therapeutic decisions. One of the most important is to consider 2 processes such as UC and $\mathrm{CD}$ in which the inflammatory activity at the level of the intestinal mucosa may differ. Tissue TNF in the inflamed mucosa is superior to anti-TNF, which explains why there are subgroups of patients that maintain the activity of the disease despite therapeutic levels of anti-TNF [27]. These differences at tissue level are evident between UC (where there is a very rapid clearance of the antibody at intestinal level) and CD, so that the therapeutic ranges can vary between both processes. Therefore, based on the available evidence, we can only suggest thresholds above which only a small proportion of patients may not be in clinical remission during maintenance treatment [28]. Aspects such as the type of disease, the inflammatory tissue activity defined not only by the level of TNF but also by the antibody present, variables involved in the pharmacokinetics of ADA, and the target to be analyzed prospectively and evaluated together will help establish the appropriate ranges in each clinical scenario.

\section{Conclusions}

In the light of the results obtained in this study, the optimal therapeutic cut-off point of serum ADA levels ranges from $4.5-5$ to $12 \mu \mathrm{g} / \mathrm{mL}$, where ADA levels are associated with an adequate clinical monitoring of the disease during maintenance therapy.

These ranges vary according to the target, suggesting levels of $4.8 \mu \mathrm{g} / \mathrm{mL}$ as the cutoff for clinical remission and

levels $\geq 7.5 \mu \mathrm{g} / \mathrm{mL}$ for mucosal healing/endoscopic response. Prospective controlled studies should be conducted to determine the optimal therapeutic interval of serum ADA levels and compare the clinical outcomes of TDM in combination with clinical status vs. clinical status monitoring alone. Research should be done both on maintenance and on induction therapy and in patients with CD and with UC.

\section{Acknowledgments}

All authors thank Meisys for the bibliographic search and systematic review, data collection, and filtering.

\section{Statement of Ethics}

The authors declare that they have no ethical conflicts to disclose.

\section{Disclosure Statement}

J.H. and F.M. have served as speakers, consultants, and advisory board members and have also received funding from MSD, Abbvie, Ferring, Faes Farma, Shire Pharmaceuticals, Chiesi, Otsuka Pharmaceutical, Pfizer - Hospira, Kern Pharma, UCB Pharma, Vifor Pharma, Janssen, Takeda, and Dr. Falk Pharma. G.J.M.-R. has served as a speaker, consultant, and advisory board member and has also received funding from Abbvie and MSD.

\section{Author Contributions}

Guarantor of the article: J.H. Specific author contributions: J.H. and F.M. have contributed in the data analysis, writing and manuscript review. G.J.M.-R. has participated in the manuscript review. All authors have approved of the final version of the manuscript.

References

Dig Dis 2019;37:444-450

DOI: $10.1159 / 000499870$
1 Ungar B, Levy I, Yavne Y, Yavzori M, Picard O, Fudim E, et al. Optimizing Anti-TNF-a Therapy: Serum Levels of Infliximab and Adalimumab Are Associated With $\mathrm{Mu}$ cosal Healing in Patients With Inflammatory Bowel Diseases. Clin Gastroenterol Hepatol. 2016 Apr;14(4):550-57.e2.

2 Adalimumab. Summary of product characteristics. Euorpean Medicines Agency. http:// www.ema.europa.eu/docs/en_GB/document_library/EPAR_-_Product_Information/human/004212/WC500225278.pdf. 
3 Hanauer SB, Sandborn WJ, Rutgeerts P, Fedorak RN, Lukas M, MacIntosh D, et al. Human anti-tumor necrosis factor monoclonal antibody (adalimumab) in Crohn's disease: the CLASSIC-I trial. Gastroenterology. 2006 Feb;130(2):323-33.

4 Sandborn WJ, Hanauer SB, Rutgeerts P, Fedorak RN, Lukas M, MacIntosh DG, et al. Adalimumab for maintenance treatment of Crohn's disease: results of the CLASSIC II trial. Gut. 2007 Sep;56(9):1232-9.

5 Colombel JF, Sandborn WJ, Rutgeerts P, Enns R, Hanauer SB, Panaccione R, et al. Adalimumab for maintenance of clinical response and remission in patients with Crohn's disease: the CHARM trial. Gastroenterology. 2007 Jan;132(1):52-65.

6 Lin K, Mahadevan U. Pharmacokinetics of biologics and the role of therapeutic monitoring. Gastroenterol Clin North Am. 2014 Sep; 43(3):565-79.

7 Wolf D, D'Haens G, Sandborn WJ, Colombel JF, Van Assche G, Robinson AM, et al. Escalation to weekly dosing recaptures response in adalimumab-treated patients with moderately to severely active ulcerative colitis. Aliment Pharmacol Ther. 2014 Sep;40(5):486-97.

8 Strik AS, Bots SJ, D'Haens G, Löwenberg M. Optimization of anti-TNF therapy in patients with Inflammatory Bowel Disease. Expert Rev Clin Pharmacol. 2016;9(3):429-39.

9 Chiu YL, Rubin DT, Vermeire S, Louis E, Robinson AM, Lomax KG, et al. Serum adalimumab concentration and clinical remission in patients with Crohn's disease. Inflamm Bowel Dis. 2013 May;19(6):1112-22.

10 Yanai H, Lichtenstein L, Assa A, Mazor Y, Weiss B, Levine A, et al. Levels of drug and antidrug antibodies are associated with outcome of interventions after loss of response to infliximab or adalimumab. Clin Gastroenterol Hepatol. 2015;13(3):522-30.e2.

11 Imaeda $\mathrm{H}$, Takahashi K, Fujimoto $\mathrm{T}$, Bamba S, Tsujikawa T, Sasaki M, et al. Clinical utility of newly developed immunoassays for serum concentrations of adalimumab and antiadalimumab antibodies in patients with Crohn's disease. J Gastroenterol. 2014 Jan; 49(1):100-9.

12 Mitrev N, Leong RW. Therapeutic drug monitoring of anti-tumour necrosis factor- $a$ agents in inflammatory bowel disease. Expert Opin Drug Saf. 2017 Mar;16(3):303-17.

13 Mitrev N, Vande Casteele N, Seow CH, Andrews JM, Connor SJ, Moore GT, et al. Review article: consensus statements on therapeutic drug monitoring of anti-tumour necrosis factor therapy in inflammatory bowel diseases. Aliment Pharmacol Ther. 2017 Dec;46(1112): 1037-53.

14 Paul S, Moreau AC, Del Tedesco E, Rinaudo M, Phelip JM, Genin C, et al. Pharmacokinetics of adalimumab in inflammatory bowel diseases: a systematic review and meta-analysis. Inflamm Bowel Dis. 2014 Jul;20(7):1288-95.

15 Mazor Y, Almog R, Kopylov U, Ben Hur D, Blatt A, Dahan A, et al. Adalimumab drug and antibody levels as predictors of clinical and laboratory response in patients with Crohn's disease. Aliment Pharmacol Ther. 2014 Sep; 40(6):620-8.

16 Yarur AJ, Jain A, Hauenstein SI, Quintero MA, Barkin JS, Deshpande AR, et al. Higher Adalimumab Levels Are Associated with Histologic and Endoscopic Remission in $\mathrm{Pa}$ tients with Crohn's Disease and Ulcerative Colitis. Inflamm Bowel Dis. 2016 Feb;22(2): 409-15.

17 Bodini G, Savarino V, Peyrin-Biroulet L, de Cassan C, Dulbecco P, Baldissarro I, et al. Low serum trough levels are associated with post-surgical recurrence in Crohn's disease patients undergoing prophylaxis with adalimumab. Dig Liver Dis. 2014 Nov;46(11): 1043-6.

18 Bodini G, Giannini EG, Savarino V, Del Nero L, Pellegatta G, De Maria C, et al. Adalimum$\mathrm{ab}$ trough serum levels and anti-adalimumab antibodies in the long-term clinical outcome of patients with Crohn's disease. Scand J Gastroenterol. 2016 Sep;51(9):1081-6.

19 Aguas Peris M, Bosó V, Navarro B, MarquésMiñana MR, Bastida G, Beltrán B, et al. Serum Adalimumab Levels Predict Successful Remission and Safe Deintensification in Inflammatory Bowel Disease Patients in Clinical Practice. Inflamm Bowel Dis. 2017 Aug;23(8): 1454-60.

20 Roblin X, Marotte H, Rinaudo M, Del Tedesco E, Moreau A, Phelip JM, et al. Association between pharmacokinetics of adalimumab and mucosal healing in patients with inflam- matory bowel diseases. Clin Gastroenterol Hepatol. 2014 Jan;12(1):80-84.e2.

21 Feuerstein JD, Nguyen GC, Kupfer SS, FalckYtter Y, Singh S; American Gastroenterological Association Institute Clinical Guidelines Committee. American Gastroenterological Association Institute Guideline on Therapeutic Drug Monitoring in Inflammatory Bowel Disease. Gastroenterology. 2017 Sep;153(3): 827-34.

22 Yarur AJ, Abreu MT, Deshpande AR, Kerman DH, Sussman DA. Therapeutic drug monitoring in patients with inflammatory bowel disease. World J Gastroenterol. 2014 Apr;20(13):3475-84.

23 Papamichael K, Baert F, Tops S, Assche GV, Rutgeerts P, Vermeire S, et al. Post-Induction Adalimumab Concentration is Associated with Short-Term Mucosal Healing in Patients with Ulcerative Colitis. J Crohn's Colitis. 2017 Jan;11(1):53-9.

24 Brandse JF, Mould D, Smeekes O, Ashruf Y, Kuin S, Strik A, et al. A Real-life Population Pharmacokinetic Study Reveals Factors Associated with Clearance and Immunogenicity of Infliximab in Inflammatory Bowel Disease. Inflamm Bowel Dis. 2017 Apr;23(4):650-60.

25 Yarur AJ, Jain A, Sussman DA, Barkin JS, Quintero MA, Princen F, et al. The association of tissue anti-TNF drug levels with serological and endoscopic disease activity in inflammatory bowel disease: the ATLAS study. Gut. 2016 Feb;65(2):249-55.

26 Morita Y, Bamba S, Takahashi K, Imaeda H, Nishida A, Inatomi O, et al. Prediction of clinical and endoscopic responses to anti-tumor necrosis factor- $\alpha$ antibodies in ulcerative colitis. Scand J Gastroenterol. 2016 Aug;51(8): 934-41.

27 Chiu YL, Rubin DT, Vermeire S, Louis E Robinson AM, Lomax KG, et al. Serum adalimumab concentration and clinical remission in patients with Crohn's disease. Inflamm Bowel Dis. 2013 May;19(6):1112-22.

28 Vande Casteele N, Herfarth H, Katz J, FalckYtter Y, Singh S. American Gastroeneterological Association institute technical review on the role of therapeutic drug monitoring in the management of inflammatory bowel disease. Gastroenterology. 2017 Sep;153(3):835-57. e6. 